\title{
Virgin Coconut Oil Processing Training at Banjar Bedauh, Carangsari Village, Badung Regency
}

\author{
A.A. Made Semariyani and I Wayan Sudiarta ${ }^{1}$ \\ \{semariyanimega65@gmail.com\} \\ ${ }^{1}$ Food Science and Technology Study Program, Faculty of Agriculture, Warmadewa University
}

\begin{abstract}
Virgin Coconut Oil processing training was carried out at the Sari Nadhi Business Study Group (KBU) in Banjar Bedauh, Carangsari Village, Badung Regency. Its purpose is to provide the right technology required to process coconut into Virgin Coconut Oil (VCO). Participants in this study are provided with adequate knowledge on entrepreneurship, business management, sanitation and hygiene in the production, packaging and marketing processes for adequate business management. The methods used in implementing this training are face-to-face interviews, counseling and hands-on practice. The activities were carried out in stages firstly by determining the appropriate counseling technology for processing VCO, production, sanitation and hygiene, counseling on entrepreneurship, business management and marketing. Secondly, direct training/practice was held on making VCOs and several evaluations until the participants truly master the technology and are able to maunfacture products independently. Thirdly, the study was facilitated to obtain a P-IRT permit from products produced from the Badung District Health Office, therefore its marketing range is wider with guaranteed safety. Fourthly, monitoring and motivation are provided to groups and members starting to pioneer the VCO processing businesses. The result showed that the output targets achieved enables the training participants with small businesses to independently make $\mathrm{VCO}$, understand entrepreneurial knowledge, and marketing management.
\end{abstract}

Keywords : VCO, Entrepreneurship, Appropriate Technology.

\section{Pendahuluan}

Kelapa (Cocus nucifera L ) merupakan tanaman serbaguna karena seluruh bagian tanamannya bermanfaat dalam kehidupan manusia sehari-hari. Pada tahun 2015, luas areal tanaman kelapa di Indonesia mencapai 3,6 juta hektar (Direktorat Jenderal Perkebunan, 2016). Secara keseluruhan luas arealnya mencapai 75.362 ha pada tahun 2015 meliputi luas areal tanaman kelapa dalam 71.916 ha, kelapa hybrida 266 ha, kelapa genjah 3.023 ha, dan kelapa deres $157 \mathrm{ha}$. Luas areal tanaman kelapa ini mengalami penurunan 2,81 persen dibandingkan tahun 2014 yang mencapai 77.544 ha, yakni untuk jenis kelapa dalam 70.905 ha, kelapa hybrida 266 ha, kelapa genjah 2.760 ha, dan kelapa deres 104 ha (BPS Provinsi Bali, 2016). 
Kelapa sebagai salah satu tanaman yang mendominasi ditanam di daerah tropis merupakan salah satu tanaman perkebunan yang sangat potensial untuk dikembangkan. Akan tetapi sampai saat ini belum dimanfaatkan secara maksimal sehingga berpeluang dipakai untuk meningkatkan pendapatan petani, masyarakat dan menambah devisa negara. Selama ini petani/pengolah hanya terfokus mengolah buah kelapa menjadi kopra untuk dibuat minyak yang sebagian besar penggunaannya sebagai minyak goreng yang merupakan sumber energi dan vitamin memiliki sifat mudah diserap serta dapat memberikan rasa gurih dan empuk pada berbagai bahan pangan yang digoreng. Sejak dahulu telah dikenal pembuatan minyak kelapa secara tradisional dengan menggunakan peralatan dan teknologi sederhana. Pengolahan secara basah dengan proses pemanasan menghasilkan rendemen dan kualitas yang rendah, kadar asam lemak bebas, kadar air dan kotoran yang masih cukup tinggi, cepat menjadi tengik dan umur simpan yang pendek. Disamping itu dalam pembuatannya memerlukan energi cukup banyak sehingga tidak efisien. Sehingga perlu dilakukan upaya-upaya memperbaiki teknik pengolahan minyak kelapa sehingga diperoleh minyak dengan mutu yang lebih baik . Salah satu produk minyak kelapa yang saat ini mempunyai peluang pasar didalam dan diluar negeri adalah Minyak kelapa murni atau lebih dikenal dengan nama "Virgin Coconut Oil ( VCO)". Berbeda dengan minyak kelapa biasa, VCO prosesnya terkontrol. Minyak kelapa murni merupakan minyak kelapa yang diperoleh dengan cara pengolahan basah daging buah kelapa atau minyak yang dibuat melalui santan kelapa dan bukan dari kopra. Minyak kelapa murni memiliki ciri-ciri antara lain berwarna bening dan berbau harum khas minyak kelapa serta mempunyai umur simpan sampai satu tahun. Minyak kelapa murni memiliki beberapa keunggulan, diantaranya mengandung asam laurat tinggi (mencapai 48 - $50 \%$ ) dan mengandung asam lemak bebas (FFA) yang sangat rendah yaitu 0,01\% dan kadar air yang rendah pula, sehingga memiliki daya penyembuhan dan tahan terhadap ketengikan.

Penelitian yang dilakukan oleh Fakultas MIPA-UGM Yogyakarta mendapatkan bahwa minyak kelapa murni mengandung asam laurat, asam kaprilat dan asam kaprat. Ketiga jenis asam lemak ini berkhasiat sebagai anti mikroba alamiah yang dapat menghambat pertumbuhan virus, bakteri dan patogen lain serta dapat membantu untuk membangun sistem kekebalan tubuh. VCO juga mengandung tokoferol $(0,03 \%)$ dan betakaroten yang berfungsi sebagai antioksidan untuk mencegah penuaan dini dan menjaga vitalitas tubuh, dan juga menurunkan kebutuhan vitamin E. Saat ini minyak kelapa murni banyak dimanfaatkan untuk perawatan kesehatan disamping juga digunakan sebagai bahan baku untuk kosmetika, farmasi dan pembuatan susu formula. Mengkonsumsi minyak kelapa murni secara teratur dapat mengatasi beberapa jenis penyakit yang disebabkan oleh perkembangan virus dan bakteri didalam tubuh manusia. Saat ini minyak kelapa murni juga digunakan sebagai obat untuk terapi penyakit yang disebabkan oleh virus seperti Hepatitis C, HIV, influenza, herpes, kandida dan lain-lain.

Teknologi pembuatan minyak kelapa murni tergolong mudah dan sederhana yang merupakan modifikasi dari cara pengolahan minyak kelapa secara tradisional, sehingga dapat dilakukan pada skala kecil /.industri rumah tangga maupun skala besar (pabrik). Minyak VCO diperoleh hanya dengan perlakuan mekanis dan pemanasan minimal, karena tidak melalui pemanasan yang tinggi maka vitamin $\mathrm{E}$ dan enzim yang terkandung didalam daging buah kelapa dapat dipertahankan. Dapat dibuat dengan tanpa pemanasan dengan perlakuan phisik atau dengan cara fermentasi yang memanfaatkan enzim atau mikroba penghasil enzim yang dapat memecahkan ikatan antara protein, lemak dan karbohidrat. Bahan dasarnya adalah daging buah kelapa yang telah tua (berumur $10-12$ bulan ). Jenis kelapa yang baik adalah jenis kelapa dalam dan hibrida lokal karena daging buahnya tebal dan kadar minyaknya tinggi. 
Mengingat potensi pasar dan kebutuhan produk olahan kelapa khususnya minyak VCO untuk kesehatan maka diperlukan usaha dan upaya untuk menguasai teknologi pengolahannya sehingga dapat menjadi usaha baru dan dapat menambah penghasilan masyarakat melalui berbagai kegiatan dan wadah yang dapat menghimpun warga dalam bentuk kelompok Belajar Usaha. Kelompok Belajar Usaha (KBU) "Sari Nadhi" berada di Banjar Bedauh Desa Carangsari Kabupaten Badung merupakan kelompok Belajar Usaha yang dibentuk oleh masyarakat dibanjar setempat pada tanggal 23 Nopember 2018 lalu. Beranggotakan 12 orang yang terdiri dari ibu-ibu rumah tangga yang tidak mempunyai pekerjaan tetap dan sudah di berikan surat Keputusan oleh Perbekel Desa Carangsari melalui SK Nomor 39 tahun 2018 dengan pembina dan pendamping dari Program Studi Ilmu dan Teknologi Pangan Fakultas Pertanian Universitas Warmadewa yang ditugaskan dalam kegiatan Pengabdian Masyarakat dalam bentuk program pemberdayaan masyarakat pada bulan Juli- Agustus tahun 2018 yang lalu secara khusus untuk mengolah buah kelapa yang dihasilkan oleh masyarakat setempat dan kemudian pendampingan dan pembinaan kelompok selanjutnya dilakukan oleh Program Studi Ilmu dan Teknologi Pangan FP Unwar sebagai KBU Binaan. Berdasarkan hasil monitoring dan evaluasi terhadap pelaksanaan kegiatan sebelumnya oleh Tim Pengabdian Prodi Ilmu dan Teknologi Pangan serta kelihan Dinas Banjar Bedauh kegiatan sebelumnya telah berlangsung dengan sukses. Imbas dari pelaksanaan kegiatan ini ternyata menimbulkan rasa antusias anggota kelompok KBU dan tokoh-tokoh masyarakat setempat. Berkenaan dengan lancarnya kegiatan tersebut dan telah dirasakan imbasnya untuk memotivasi masyarakat dalam merintis usaha kecil maka Ketua Kelompok KBU memohon secara resmi kepada Program Studi Ilmu dan Teknologi Pangan Fakultas Pertanian Universitas Warmadewa agar dilakukan kegiatan pelatihan lanjutan dengan memilih materi pelatihan dengan tetap berbasis kelapa berupa pembuatan VCO. Sebagai salah satu tanaman yang potensial terdapat di desa Carangsari saat ini harga buah kelapa sangat murah bahkan pada saat panen raya harga buah kelapa hanya Rp.2000,- perbuah sedangkan ongkos panjat cukup mahal yaitu Rp.20.000,- perpohon. Dengan murahnya harga buah kelapa yang mereka hasilkan maka muncul pemikiran untuk mngolahnya menjadi minyak VCO sehingga nilai ekonomis buah kelapa dapat lebih ditingkatkan dan dapat menambah pendapatan masyarakat.

Dari data profil Desa Carangsari sebagian besar warganya yaitu $60 \%$ beraktivitas aktif dalam hal bercocok tanam atau agraris. Desa Carangsari yang dikenal sebagai desa wisata. Penduduk Desa Carangsari mayoritas beragama Hindu dengan jumlah penduduk akhir Desember 2017 sebanyak 5.774 jiwa, yang terdiri dari laki-laki: 2.817 jiwa dan perempuan: 2.957. masyarakat Banjar Bedauh sebagian dari penduduknya adalah sebagai petani sawah dan kebun dan kebanyakan ibu-ibu rumah tangga tidak mempunyai pekerjaan tetap. Adapun tanaman perkebunan yang potensial ditanam masyarakat adalah kakao dan kelapa.

Dengan data ini untuk menekan angka keluarga yang tidak mempunyai pekerjaan tetap terutama ibu-ibu rumah tangga maka diusulkan kegiatan pengabdian kepada Masyarakat berupa pelatihan pengolahan berbasis kelapa berupa minyak VCO melalui Dana hibah Institusi Universitas Warmadewa tahun 2019 ini.

Dengan kegiatan pengabdian kepada masyarakat yang didanai oleh Unwar, diharapkan masyarakat di Banjar Bedauh Desa Carangsari Badung memiliki keterampilan dan wawasan dalam mengelola sumber daya alam setempat. Dengan diberikan kegiatan pelatihan teknologi pengolahan VCO diharapkan masyarakat mampu memproduksi dan memasarkan produk olahannya serta dapat meningkatkan kesejahteraan masyarakat. 


\section{Metode Penelitian}

Metode pelaksanaan kegiatan PKM Pelatihan pengolahan buah kelapa menjadi minyak VCO menggunakan:

1. Metoda diskusi untuk dapat mengetahui permasalahan yang dialami mitra.

2. Metoda tatap muka dan memberikan penyuluhan secara langsung, agar mitra mendapatkan pengetahuan mengenai pengolahan buah kelapa menjadi minyak VCO dengan metode pembuatan yang sederhana dengan peralatan yang sederhana pula, kewirausahaan dan managemen usaha.

3. Praktek langsung, yang dipandu oleh instruktur dari kalangan dosen, alumni dan mahasiswa yang telah menempuh mata kuliah Teknologi minyak-lemak, sehingga mitra dapat membuat langsung produk yang diberikan.

\section{Hasil dan Pembahasan}

Setelah ditanda tanganinya berita acara penggunaan dana $70 \%$ dalam pelaksanaan hibah pengabdian masyarakat Universitas Warmadewa bertempat di Lembaga Pengabdian Masyaraka (LPM) Unwar pada pada hari Senin tanggal 27 Mei 2019 maka segera dilakukan tindak lanjut melakukan pelaksanaan kegiatan sesuai dengan jadwal yang sudah direncanakan dengan tetap mempertimbangkan dan menyesuaikan kegiatan-kegiatan yang sedang dilaksanakan oleh masyarakat di Banjar Bedauh, Desa Carangsari khususnya anggota Kelompok Belajar Usaha (KBU) Sari Nadhi yang menjadi mitra dalam PKM ini.

Sebagai tahap awal telah dilakukan pendekatan dan berkoordinasi dengan Kepala Desa Carangsari, kepala lingkungan/Klian Dinas Banjar Bedauh dan ketua KBU untuk mematangkan rencana kegiatan pelatihan yang sudah disepakati saat penjajagan sebelum proposal ini disetujui oleh pihak LPM Unwar. Pertemuan dilakukan pada hari Kamis, 20 Juni 2019 dengan mengambil tempat di rumah salah satu anggota kelompok. Adapun yang diundang antara lain Kepala Desa Carangsari, Kepala Lingkungan / Klian Banjar Bedauh, Ketua serta anggota KBU Sari Nadhi. Pada pertemuan tersebut telah disepakati semua anggota KBU yang berjumlah 12 orang ikut dalam Pelatihan Pembuatan VCO. Selanjutnya mereka dibagi menjadi 2 kelompok (6 orang untuk masing-masing kelompok) untuk memudahkan dalam praktek pembuatan VCO sehingga semuanya bisa mengerjakan dan tahu tahap-tahapan proses pembuatan $\mathrm{VCO}$. 
Pada hari Selasa, 9 Juli 2019 dilakukan pertemuan dengan semua peserta pelatihan yang dihadiri oleh Kepala Desa, Kepala Lingkungan/Klian Banjar Bedauh, Ketua KBU Sari Nadhi serta semua anggota Kelompok. Adapun kegiatan yang dilakukan pada saat itu antara lain :

1. Pembukaan kegiatan pelatihan pengolahan Kelapa menjadi VCO oleh Kepala Desa Carangsari selaku pelindung dan penasehat Kelompok Belajar Usaha yang menjadi mitra kegiatan ini

2. Uraian dari Ketua Tim tentang kegiatan Tri Dharma Perguruan Tinggi khususnya kegiatan pengabdian masyarakat Unwar serta rencana kegiatan pelatihan yang akan dilaksanakan sehingga semua peserta dan instruktur yang akan mendampingi selama kegiatan dapat menyamakan persepsi dan kegiatan menjadi lancar.

3. Diskusi dan tanya jawab mengenai permasalahan yang dihadapi mitra, sekaligus merencanakan kegiatan ini yang menunjukan langkah-langkah solusi atas persoalan yang dihadapi.

4. Dilakukan penyerahan peralatan yang akan disumbangkan kepada mitra untuk mendukung pembuatan produk dalam pelatihan dan berproduksi lebih lanjut.

5. Pembagian modul pembelajaran sehingga peserta pelatihan dapat belajar dan mengikuti pelatihan dengan lebih lancar.

6. Membuat kesepakatan jadwal kegiatan dengan peserta pelatihan sehingga peserta pelatihan dapat mengatur waktu kegiatannya dan kegiaatan dapat berlangsung sesuai rencana dan dari segi waktu dapat efisien dan menyesuaikan dengan aktifitas peserta. Disepakati dalam pertemuan tersebut pelatihan akan dipusatkan di rumah salah satu anggota KBU dan dimulai pada tanggal 20 Juli 2019.

Pada pertemuan I dilaksanakan kegiatan ceramah sebagai materi penunjang/umum. Untuk kegiatan ini peserta didik diberikan ceramah mengenai :

1. Kebijakan dan Arah Pendidikan Non formal yang diberikan oleh Instruktur Ir. A.A. Made Semariyani, M.Si dan Ir. I Wayan Sudiarta, M.P.

2. Kebijakan dan pentingnya perijinan produk olahan bagi masyarakat yang diberikan oleh Instruktur Ir. A.A. Made Semariyani, M.Si

3. Kewirausahaan, penguatan kelembagaan, kemitraan, kewirausahaan dan pemasaran diberikan oleh Ir. I Gusti Ngurah Sugiana, M.Agb

4. Perlindungan konsumen, sanitasi, higiene, pengemasan dan labelling produk yang diberikan oleh Ir. A.A. Made Semariyani,M.Si

5. Materi khusus berupa : tinjauan tentang kelapa dan prospeknya sebagai bahan baku olahan VCO serta nilai gizi dan manfaatnya diberikan oleh Ir. I Wayan Sudiarta,M.P. dibantu oleh Alumni dan Mahasiswa dari Program Studi Ilmu dan Teknologi Pangan Universitas Warmadewa.

Untuk kegiatan ceramah ini panitia menyediakan modul pelatihan yang berisi materimateri dari ceramah di atas serta modul pelatihan pembuatan VCO. Dengan cara seperti ini diharapkan peserta didik mendapatkan pemahaman mengenai materi ceramah yang berkaitan dengan kewirausahaan dan memiliki file - file yang sewaktu-waktu dapat diambil jika peserta didik lupa dengan teori dan bahan dari pelatihan. Materi diberikan sedemikian 
rupa sehingga peserta pelatihan akan terbuka wawasannya dan bersemangat untuk mengukuti pelatihan.

Pada pertemuan ke II diberikan Pelatihan Mengenai Pembuatan Virgin Coconut Oil (VCO). Peserta didik dituntun oleh instruktur yang berasal dari Dosen di Program Studi Ilmu dan Teknologi Pangan, Fakultas pertanian, Unwar. Diharapkan peserta didik dapat mengikuti dengan baik, pelatihan yang diberikan. Peserta pelatihan dibimbing oleh instruktur. Pada setiap pertemuan dilakukan evaluasi kegiatan dan monitoring sehingga pada setiap pertemuan kekurangan dan kesalahan dapat dilakukan perbaikan dengan segera pada pertemuan-pertemuan berikutnya.

Pada pertemuan ke III anggota kelompok membuat sendiri VCO tanpa dituntun oleh instruktur hasilnya dievaluasi dimana letak kekurangannya agar nantinya diperbaiki pada pertemuan berikutnya. Pada Pertemuan ke IV pelatihan kembali dilakukan dengan memberikan materi yang sama seperti pada pertemuan ke ke III dalam artian kelompok diberikan kebebasan dalam membuat VCO dan hasilnya dievaluasi kembali untuk mendapatkan VCO dengan kualitas yang baik.

Produk hasil pelatihan ini kemudian dinilai apakah sudah sesuai dengan hasil akhir produk yang diharapkan yang kemudian menjadi bahan pertimbangan apakah sudah memenuhi kriteria untuk mengajukan permohonan untuk mendapatkan ijin produk berupa ijin Produk Industri Rumah tangga (PIRT). Disamping itu diharapkan juga kepada anggota kelompok mencoba membuat sendiri produk yang telah dilatih tersebut dan memasarkannya baik secara manual (dari mulut ke mulut), dan promosi secara on line. Berdasarkan hasil evaluasi yang dilakukan dan berdasarkan hasil diskusi antara instruktur, peserta pelatihan, Ketua kelompok dan Kepala Desa Carangsari maka telah disepakati produk VCO akan diupayakan untuk dicarikan ijin produk P-IRT sehingga mendapat rekomendasi dari Dinas Kesehatan Kabupaten Badung yang akan dipakai sebagai lampiran permohonan sertifikat penyuluhan keamanan pangan dan sertifikat produksi P-IRT ke Dinas Penanaman Modal dan Pelayanan Terpadu Satu pintu Kabupaten Badung. Pengajuan permohonan ijin P-IRT untuk produk VCO ini akan dilakukan setelah memenuhi semua persyaratan administrasi yang ditentukan. Harapan kedepannya produk VCO ini akan menjadi icon Banjar Bedauh, Desa Carangsari Kecamatan Petang, Kabupaten Badung. Disamping itu apabila ijin P-IRT telah terbit, maka pemasaran produk VCO bisa menjadi lebih luas tidak saja di pasar tradisional, tetapi juga akan bisa dijual di Toserba, mini Market dan Pasar swalayan karena telah dilengkapi ijin sebagai legalitas produk. Rencananya KBU Sari Nadhi ini juga akan menerima order VCO untuk keperluan salon dan spa.

Rangkuman pelaksanaan kegiatan sebagai solusi untuk menyelesaikan permasalahan serta persentase capaian target yang sudah dicapai seperti pada Tabel 1.

Tabel 1. Capaian target Luaran Kegiatan

\begin{tabular}{|c|c|c|c|c|}
\hline No & Permasalahan & Solusi/Kegiatan & Target Luaran & $\begin{array}{c}\text { Capaian target } \\
\text { Luaran }\end{array}$ \\
\hline 1 & $\begin{array}{l}\text { Kelompok yang } \\
\text { tidak aktif }\end{array}$ & $\begin{array}{l}\text { Mengaktifkan kelompok } \\
\text { dengan peremajaan / } \\
\text { pergantian } \\
\text { kelompok }\end{array}$ & $\begin{array}{l}\text { Kelompok belajar } \\
\text { usaha yang ada } \\
\text { menjadi terbentuk } \\
\text { kembali }\end{array}$ & $\begin{array}{l}\text { Kelompok telah aktif } \\
\text { dan dapat mengikuti } \\
\text { pelatihan }(100 \%)\end{array}$ \\
\hline
\end{tabular}




\begin{tabular}{|c|c|c|c|c|}
\hline No & Permasalahan & Solusi/Kegiatan & Target Luaran & $\begin{array}{l}\text { Capaian target } \\
\text { Luaran }\end{array}$ \\
\hline 2 & $\begin{array}{l}\text { Iptek pengolahan } \\
\text { VCO }\end{array}$ & Ceramah dan pelatihan & $\begin{array}{l}\text { Peningkatan } \\
\text { pemahaman dan } \\
\text { ketrampilan peserta } \\
\text { pelatihan }\end{array}$ & $\begin{array}{l}\text { Telah dilakukan } \\
\text { ceramah, penyuluhan } \\
\text { dan pelatihan }(100 \%)\end{array}$ \\
\hline 3 & $\begin{array}{l}\text { Pengetahuan } \\
\text { kewirausahaan dan } \\
\text { pemasaran produk }\end{array}$ & Ceramah/penyuluhan & $\begin{array}{l}\text { Peserta memahami } \\
\text { kewirausahaan dan } \\
\text { pemasaran produk }\end{array}$ & $\begin{array}{l}\text { Telah dilakukan } \\
\text { ceramah dan } \\
\text { penyuluhan }(100 \%)\end{array}$ \\
\hline 4 & $\begin{array}{l}\text { Sanitasi } \\
\text { higiene }\end{array}$ & Ceramah/penyuluhan & $\begin{array}{l}\text { Peserta pelatihan } \\
\text { memahami tentang } \\
\text { pentingnya sanitasi } \\
\text { dan higiene }\end{array}$ & $\begin{array}{l}\text { Telah dilakukan } \\
\text { ceramah dan } \\
\text { penyuluhan }(100 \%)\end{array}$ \\
\hline 5 & $\begin{array}{l}\text { Pengemasan dan } \\
\text { labelling }\end{array}$ & Ceramah/penyuluhan & $\begin{array}{lr}\text { Peserta memahami } \\
\text { pentingnya } & \text { teknik } \\
\text { pengemasan } & \text { dan } \\
\text { labelling } & \end{array}$ & $\begin{array}{l}\text { Telah dilakukan } \\
\text { ceramah dan } \\
\text { penyuluhan }(100 \%)\end{array}$ \\
\hline 6 & Ijin Produk & $\begin{array}{ll}\text { Memfasilitasi } & \text { permohonan } \\
\text { ijin produk } & \text { di Dinas } \\
\text { kesehatan } & \text { Kabupaten } \\
\text { Badung } & \end{array}$ & $\begin{array}{l}\text { Produk olahan susu } \\
\text { jagung manis } \\
\text { memiliki ijin produk } \\
\text { PIRT }\end{array}$ & $\begin{array}{l}\text { Telah mengajukan ijin } \\
\text { P-IRT dan menunggu } \\
\text { jadwal untuk } \\
\text { diverifikasi dan uji } \\
\text { laboratorium }\end{array}$ \\
\hline 7 & $\begin{array}{l}\text { Peralatan } \\
\text { pengolahan } \\
\text { produk VCO }\end{array}$ & $\begin{array}{lr}\text { Bantuan } & \text { peralatan } \\
\text { penyimpanan } & \text { dan } \\
\text { pengolahan } & \end{array}$ & $\begin{array}{l}\text { Adanya alat-alat } \\
\text { untuk pelatihan dan } \\
\text { untuk berproduksi } \\
\text { selanjutnya }\end{array}$ & $\begin{array}{ll}\text { Sudah } & \text { diberikan } \\
\text { bantuan } & \text { peralatan } \\
(100 \%) & \end{array}$ \\
\hline 9 & Peningkatan omzet & $\begin{array}{l}\text { Meningkatkan dengan } \\
\text { alternatif produk baru }\end{array}$ & $\begin{array}{l}\text { Jumlah produksi } \\
\text { meningkatkan }\end{array}$ & $\begin{array}{l}\text { Belum tercapai karena } \\
\text { masih pada tahap } \\
\text { perintisan } \\
\text { pendampingan }\end{array}$ \\
\hline 9 & Publikasi Ilmiah & $\begin{array}{l}\text { Mengupayakan publikasi } \\
\text { pada jurnal pengabdian } \\
\text { masyarakat }\end{array}$ & Terpublikasi & Terpublikasi \\
\hline
\end{tabular}

\section{Kesimpulan}

1. Peserta pelatihan telah mengikuti pelatihan dengan semangat dan disiplin terlihat dari daftar kehadirannya.

2. Pelatihan untuk pembuatan produk berupa Virgin Coconut Oil (VCO) dapat dilaksanakan dengan baik dan peserta pelatihan mampu membuat produk tersebut dengan baik 
3. Target luaran dari kegiatan PKM Pelatihan Pembuatan VCO ini telah diberikan kepada peserta didik, kecuali untuk memfasilitasi P-IRT dari Dinas Kesehatan Kabupaten Badung masih menunggu jadwal untuk diverifikasi dan uji laboratorium.

\section{References}

[1] Badan POM. 2003. Higiene dan Sanitasi Pengolahan Pangan. Direktorat Surveylan dan Penyuluhan Keamanan Pangan. Deputi Bidang Pengawasan Keamanan Pangan dan Bahan Berbahaya. Badan Pengawas Obat dan Makanan. Jakarta.

[2] Buckle, K.A., R.A. Edwards, G.H. Fleet dan M. Wootton. 2010. Ilmu Pangan. Penerjemah Purnomo dan Adiono. UI Press. Jakarta.

[3] Buda.1981. Kelapa dan Hasil Olahannya. Bagian Teknologi Pertanian. Fakultas Pertanian Universitas Udayana. Denpasar

[4] Direktorat Jenderal Perkebunan. 2016. Buku Statistika Kelapa (Coconut). Diakses pada ditjenbun.pertanian.go.id/tinymcpuk/gambar/file/statistik/2017/Kelapa-2015-2017.pdf. (diakses 26 Maret 2018).

[5] Ketaren, S dan Djatmiko.1978. Daya Guna Hasil Kelapa. Departemen Teknologi Hasil Pertanian. Fatemeta,IPB. Bogor.

[6] Ketaren, S. 1986. Pengantar Teknologi Minyak dan Lemak Pangan. Cetakan Pertama. Jakarta : UI-Press.

[7] Palungkun, R. 2004. Aneka Produk Olahan Kelapa. Penerbit Swadaya.Bogor.

[8] Nugroho, S.P. 2010. Karakteristik Usaha Kecil di Indonesia. Perencanaan Pemasaran Usaha Kecil Rumahan. Benefit Jurnal Manajemen dan Bisnis. Vol 14, No 1. 2010. Hal. 22-27 